\title{
The nutritive value of the indigenous grasses of Surinam
}

\author{
J. G. P. DIRVEN ${ }^{1}$
}

Department of Field Crops and Grassland Husbandry of the Agricultural University, Wageningen, Netherlands

\section{Summary}

The contents of crude protein, crude fibre, ash, $\mathrm{K}, \mathrm{Na}, \mathrm{Ca}, \mathrm{Mg}, \mathrm{P}, \mathrm{Cl}$ and $\mathrm{S}$ as well as the pepsin-digestible crude protein have been determined in 69 herbage samples of natural grasslands in Surinam.

Moreover, the trace elements cobalt, copper and molybdenum have also been analysed in 19-24 samples. In general it may be said that the protein contents are on the low side; an exception are the aquatic grasses. The content of crude fibre is high in all samples. Dairy cattle with a reasonable production level needs some special attention in terms of calcium and phosphorus nutrition. The sodium contents are uncommonly low. In view of the high temperatures additional sodium should be applied to cattle. Moreover, additional cobalt and copper is necessary as well. This supplementary feeding is feasible by means of placing mineral boxes with mixtures of common salt, steamed bone meal and trace elements in the pasture. Undoubtedly this method will prove to be cheaper than covering the mentioned deficiencies by means of fertilization.

\section{Introduction}

The Surinam livestock population runs to about 36.000 heads of cattle and is composed of 15.300 dairy cows, 9.250 heifers and 11.500 bulls and bullocks (DEL Prado, 1961). Milk yield and meat production of cattle are low. The slaughter weight is $125 \mathrm{~kg}$ on an average, while the milk yield is about 7001 per lactation period. Undoubtedly, this low production level is partly due to the type of cattle, but besides, the warm humid climate as well as insufficient nutrition and care of cattle are limiting factors for high yields.

Especially the nutrition shows serious imperfections. In many cases there is a shortage of roughage. On sandy and loamy soils cattle often is short of grass. In the rainy season, when the paddy is grown on the field, not enough grass is available at farms on clay soil and the animals are put to pasture in commons or on dikes and road sides. Sometimes grass is cut elsewhere and the cattle is barn fed.

Besides having a low productivity, the grassland is also of an inferior quality. This is quite obvious from research carried out by J. SACK, P. MULler and H. J. Mülller, published by Frickers (1941). In 24 grass samples the content of crude protein, true protein, fat, crude fibre and ash were determined; likewise in 14 samples the contents of calcium, phosphorus and cilicic acid. In sequel of this DiRven (1953)

1 During the years 1951-1962, the author was employed at the Agricultural Experiment Station and the Government Livestock Farm, Paramaribo, Surinam.

Received for publication 15th June, 1963. 
sampled some ten grasslands. Besides the above-mentioned contents also those of potassium, sodium and magnesium were determined in the samples. These more or less informative investigations have proved that the protein content is rather low in the indigenous grasses; the crude-fibre content, however, is high. The contents of calcium, phosphorus and sodium appeared to be insufficient.

In view of the livestock-improvement program introduced by the government, a more systematical investigation into the nutritional value of indigenous grasses was necessary. As a result samples were taken in 1955, 1956 and 1959.

\section{Method of research}

The samples were taken in such a way as to get a general idea of the average chemical composition of the roughage consumed. As at least $2 / 3$ of the cattle population pastures in the district Surinam, $70 \%$ of the samples have been taken in this district; the remaining samples come from the districts Commewijne, Coronie, Nickerie and Saramacca. In sampling due attention has been payed to soil type, drainage and dominant species. The distribution of the samples over the various types of grassland is shown in TABLE 1.

In total 69 samples were taken and, after drying, sent for analysis to the Netherlands. Of these 52 were analysed by the Chemistry Department of the former Central Institute of Agricultural Research at Wageningen; the other 17 samples were analysed by the Laboratory for Soil and Crop Testing at Oosterbeek.

TABLE 1. Distribution of samples according to soil type, drainage and dominant plant species

Soil type Number Dominant plant species

Sand and loam

a. Carpet-grass pastures .....

b. remaining grass species ...

8

8

Clay

a. creeks, ditches, swamps.

21

b. pastures on drier clay soils

16

c. paddy fields

d. grasslands along the sea (salt habitat)
Axonopus compressus.

Brachiaria purpurascens, Panicum laxum, Paspalum conjugatum, Paspalum maritimum, Stenotaphrum secundatum.

Hymenachne amplexicaulis, Hymenachne donacifolia, Leersia hexandra, Luziola spruceana, Echinochloa polystachya.

Acroceras zizanioides, Brachiaria purpurascens, Cynodon dactylon, Eriochloa polystachya, Fimbristylis miliacea, Hymenachne amplexicaulis, Leersia hexandra, Panicum laxum, Paspalum conjugatum.

Fimbristylis miliacea, Leersia hexandra, Hymenachne amplexicaulis, Panicum laxum, Paspalum conjugatum.

3 Paspalum vaginatum.

\section{Results}

3.1. Average chemical composition of the indigenous grasses

In calculating the average chemical composition of natural grasslands the occurrence of various types of grassland has been taken into account. The following estimation 
has been used to this purpose: $25 \%$ of the Surinam cattle population grazes on sandy and loamy soils, i.e. $15 \%$ on Axonopus compressus (Carpet grass) and $10 \%$ on other grass fields. About $75 \%$ is put to pasture on clay soils, i.e. $30 \%$ on drier clay soils, fallow fields, commons and road sides, $30 \%$ on the vegetation of paddy fields after the crop has been harvested and $15 \%$ on grasses in creeks and swamps.

The latter grasses, however, are also cut sometimes and fed to cattle in the barn. The average chemical composition thus calculated is shown in TABLE 2 .

TABLE 2. Average chemical composition of indigenous grasses, expressed in percentages of dry matter

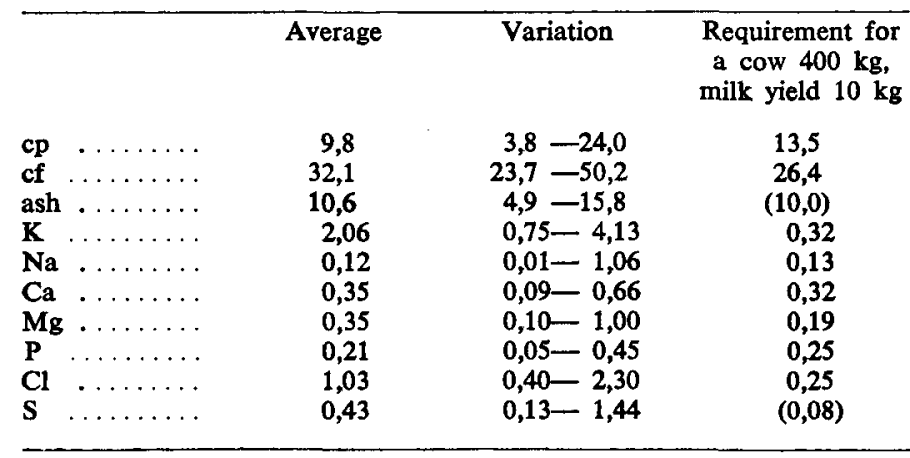

To enable a correct interpretation of the nutritive value of the indigenous grasses the nutritional requirement of a cow of $400 \mathrm{~kg}$ live weight and a daily milk yield of $10 \mathrm{~kg}$ milk ( $4 \%$ fat) may be set as a standard. Such animals are to be found on the better managed farms, while moreover, every farmer can acquire this kind of cattle $(2000 \mathrm{~kg}$ milk per lactation period) by means of artificial insemination with Friesian blood. As the daily dry-matter intake of these animals is estimated at $10 \mathrm{~kg}$ (Appelman, Dirven, Tuong A Hung, 1962) the desired composition of the grass can be easily calculated. According to the standards of LARS FREDERIKSEN, used in temperate areas, the daily requirement for maintenance and production of this animal will be $936 \mathrm{~g}$ digestible crude protein and $5108 \mathrm{~g}$ starch equivalent. Investigations of Dukstra and DiRven (1962) have proved that in this case the content of crude protein in the herbage should be put at $13,5 \%$ of the dry matter at least. A content of $26,4 \%$ of crude fibre should be considered a maximum. Only $6 \%$ of all samples analysed met this requirement. The average starch equivalent of the herbage is $416 \mathrm{~g}$ per $\mathrm{kg}$ dry matter. The nutritional value of the Surinam grasslands corresponds to that of hay in the temperate areas. Evidently, high milk yields cannot be obtained on this roughage without supplementary concentrate feeding. The variation in the crude-protein and crude-fibre content, however, shows that there also are grass fields with a higher nutritive value.

By determining the digestibility of protein in pepsin $\mathrm{HCl}$ an attempt has been made to gain an impression of the digestible crude-protein content of grasses. Therefore, the contents of crude protein $\left(\mathrm{x}^{\prime \prime}\right)$ and pepsin-digestible crude protein $\left(\mathrm{d}^{\prime \prime}\right)$, both in percentages of organic matter, have been plotted against each other in FIG. 1. There appeared to be a straight-line relationship $\mathrm{d}^{\prime \prime}=0,760 \mathrm{x}^{\prime \prime}-1,87$ between these two contents. Due to their deviating pepsin digestibility the samples of Paspalum conjugatum (Sour grass) have been left out of consideration in calculating this re- 
Fig. 1. Relation between crude protein and pepsin-digestible crude protein. The dotted line reflects the relation between crude protein and animal-digestible crude protein

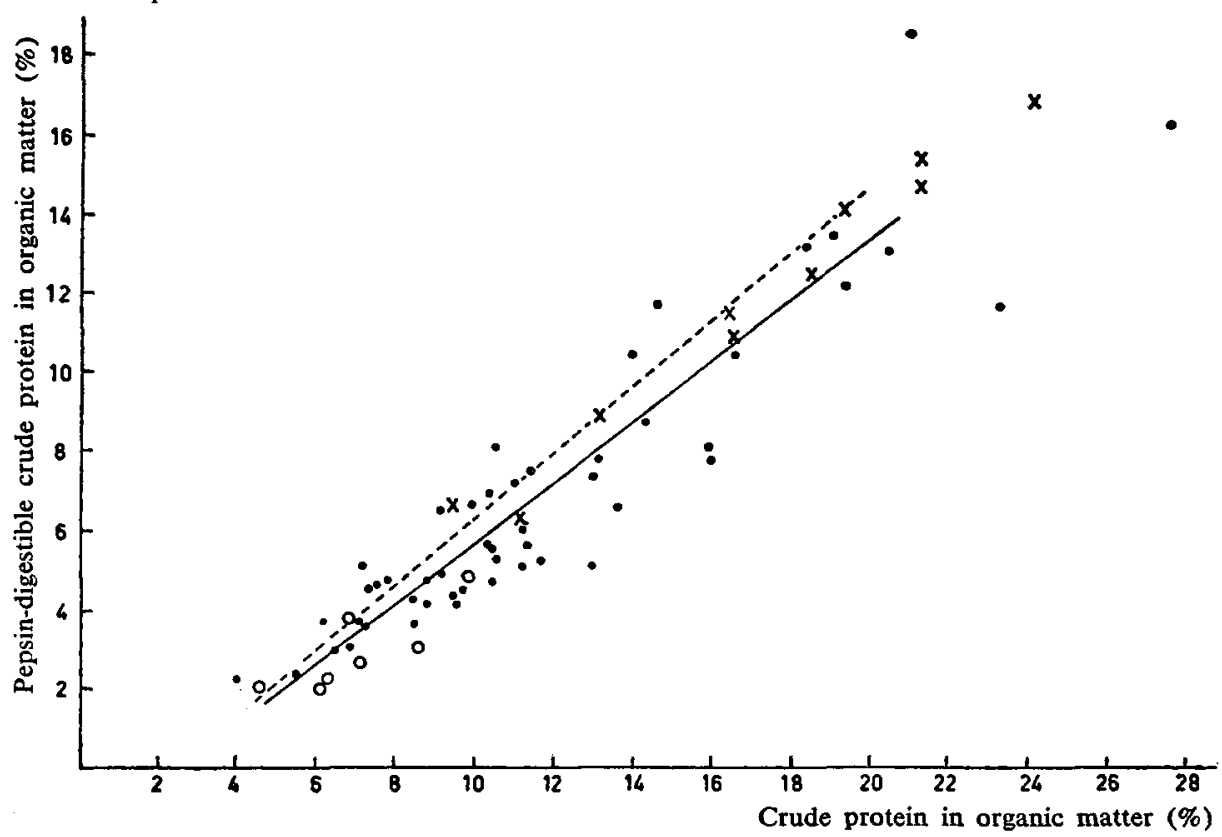

O samples of Paspalum conjugatum

$\times$ samples of Hymenachne amplexicaulis

- remaining samples

gression line. The regression line $d=0,827 \mathrm{x}-1,987$ has been drawn in FIG. 1 as well. This line represents the relation between the contents of crude protein $(x)$ and animal-digestible crude protein (d), both expressed in percentages of the organic matter, of 63 digestion trials with tropical grass species (DuJKSTRA and Dirven, 1962). If the last-mentioned formula is generally accepted, it is evident that the results of the pepsin-digestible crude protein are too low. This is contradictory to what is generally found in Dutch grasses, viz. that the results of the pepsin-digestible crude protein are higher than those of the animal-digestible crude protein.

The mineral requirement has been estimated according to BROUWER and BRANDSMA (1953). This estimation is based on the opinion that the mineral proportions in the milk should be considered as favourable for nutrition. The daily requirement of magnesium, expressed in grams, has been inferred, however, from a formula found by FRENS (1962) $\mathrm{Mg}=0,02 \mathrm{G}+\mathrm{M}$, where $\mathrm{G}$ and $\mathrm{M}$ are live weight and milk yield $(3,33 \%$ fat $)$ in $\mathrm{kg}$ respectively. The desired mineral composition derived in this way has been mentioned under the fourth column of TABLE 2 .

On account of the above-mentioned considerations the average mineral composition and its variation infer that potassium, magnesium, chlorine and sulphur are present in the herbage to a liberal extent. The average contents of calcium, phosphorus and sodium are almost sufficiently high, but in a great number of herbage samples these contents are considerably below the set standard. Accordingly, the calcium content 
in $50 \%$ of the samples is below 0,32 ; in $62 \%$ the phosphorus content is below 0,25 and in $68 \%$ the sodium content is below 0,13 . As for the latter content it should further be said that sodium requirement in the tropics is much higher than it is in temperate areas. Consequently, beef cattle (live weight $350 \mathrm{~kg}$ ) had an annual intake of $24,9 \mathrm{~kg}$ common salt per animal on a grassland with $0,02 \%$ of sodium in the dry matter (APPELMan and DiRven, 1962). This corresponds to $0,30 \% \mathrm{Na}$ in the dry matter of the herbage consumed. Evidently, the application of this mineral is of importance.

As appears from the table, the differences between the lowest and highest contents are very large. This matter will be treated at length in the further course of this article.

\subsection{Soil type and drainage}

In order to explain the wide variation in the different contents the herbage samples were firstly divided according to soil type and drainage. TABLE 3 shows the average chemical composition calculated in this way.

TABLE 3. Average chemical composition, expressed in percentages of the dry matter, of grasslands on several soil types and at different drainage conditions

\begin{tabular}{|c|c|c|c|c|c|c|c|c|c|c|c|c|}
\hline & & cp & dcp & cf & ash & $\mathbf{K}$ & $\mathrm{Na}$ & $\mathrm{Ca}$ & $\mathbf{M g}$ & $\mathbf{P}$ & $\mathbf{C l}$ & $\mathbf{S}$ \\
\hline $\begin{array}{l}1 . \\
2 .\end{array}$ & $\begin{array}{l}\text { Sand and loam soils } \ldots \ldots \\
\text { Clay soils }\end{array}$ & 9,9 & 53 & 30,3 & 9,0 & 1,79 & 0,13 & 0,37 & 0,31 & 0,23 & 0,78 & 0,22 \\
\hline & a. creeks, ditches, swamps & 15,7 & 67 & 31,0 & 12,3 & 2,96 & 0,08 & 0,31 & 0,25 & 0,29 & 1.08 & 0,34 \\
\hline & b. drier clay soils $\ldots .$. & 8 & 6. & 33,5 & 10,4 & 2,10 & 0,15 & 0,31 & 0,40 & 0,21 & 1,04 & 0,53 \\
\hline & c. padc & 7 & 48 & 33 , & 11,0 & 1,78 & 0,1 & 0,39 & 0 , & 0,14 & 1,19 & 0,56 \\
\hline & d. salt & 6,8 & 54 & 36,8 & 10,4 & 1,21 & 0,23 & 0,25 & 0,19 & 0,15 & 2,00 & 0,38 \\
\hline
\end{tabular}

The larger dairy farms are generally found on sand and loam soils. Although these soils are poor in minerals, the condition of cattle is much better as a result of the better drainage than on farms on clay soil. Moreover, cattle is supplied with additional feed such as rice bran, rice polishings and cane molasses. The nutritive value of the herbage is decidedly insufficient for high milk yields. The mineral composition is not unsatisfactory, though application of additional common salt remains necessary and at some farms the phosphorus nutrition will need some more attention.

The nutritional value of the grass fields of creeks, ditches and swamps is excellent. As the content of crude fibre is relatively high, starch equivalent will be the limiting factor for high yields. The mineral composition is very favourable, though here too additional sodium has to be supplied. Cattle is often put to pasture on these grass fields in the dry season. However, sometimes this herbage is cut and barn fed. In this way good results are obtained especially for feeding purposes.

The condition of cattle on the pastures on drier clay soils generally is very moderate. As the drainage is poor these grasslands will make hard going in the rainy season, while moreover much grass is trampled and contaminated with soil particles so that the animals cannot consume enough roughage in many cases. Although the clay soils are richer in minerals than the sand and loam soils, the mineral composition is not more satisfactory due to the botanical composition and age of the herbage. The animals on rice holdings live under marginal conditions. In the rainy season paddy grows in the fields and, accordingly, cattle is put to pasture along ditches and road sides where they cannot consume enough roughage. After the crop has 
been harvested, the animals feed on the natural vegetation of these paddy fields from the end of October until mid-April. In the district of Surinam about $60 \%$ of the paddy-field vegetation consists of the grasslike weed Fimbristylis miliacea; in the district of Nickerie, however, the botanical composition of this vegetation is much more favourable. TABLE 3 clearly shows that the quality of this roughage is poor. Due to the shortage as well as the poor quality of roughage cattle frequently suffers from scour and hunger oedema on these farms. Partly owing to the occurrence of internal parasites, ana- and piroplasmosis, this results in low milk and meat production as well as a high mortality.

Finally, TABLE 3 mentions the chemical composition of grasslands on a salt habitat. These grasslands are situated along the sea and are regularly flooded by sea water. The vegetation on those soils mainly consists of Paspalum vaginatum and Eleocharis mutata. The nutritional value of these grass fields is low, which is also apparent from the poor condition of the grazing cattle.

\subsection{Grass species}

Due to the highly dominating type of growth of certain grass species some samples consist of almost one species only. Consequently, the data allow a comparison to be made of the chemical composition of some separate species. These data have been outlined in TABLE 4 .

Table 4. Average chemical composition of a few grass species, expressed in percentages of the dry matter

\section{Sand and loam soils}

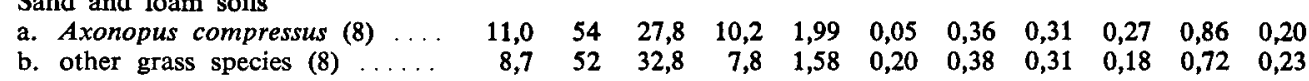

2. Clay soils

Creeks, ditches, swamps

\begin{tabular}{|c|c|c|c|c|c|c|c|c|c|c|}
\hline $\boldsymbol{H y i}$ & 15,1 & 68 & 31,5 & 11,9 & 3,39 & 0,08 & 0,20 & 0,25 & 0,30 & 1,53 \\
\hline hexandra (4) & 14 & 68 & 32,1 & 14,2 & 1,85 & 0,05 & 0,32 & 0,21 & 0,25 & 0,57 \\
\hline orucenna & 18,8 & 57 & 29,1 & 12,3 & 3,14 & 0,06 & 0,43 & 0,21 & 0,27 & 0,68 \\
\hline
\end{tabular}

3. Pastures on drier clay soils and paddy fields

a. Brachiaria purpurascens (4) $\quad \ldots \quad \begin{array}{lllllllllll}10,1 & 75 & 34,3 & 10,0 & 2,66 & 0,34 & 0,30 & 0,26 & 0,26 & 1,31 & 0,28\end{array}$

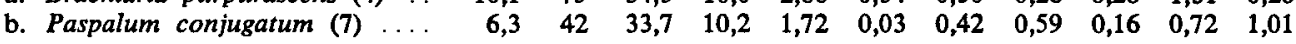

Axonopus compressus (Carpet grass) is widely distributed on the sandy soils in the neighbourhood of Paramaribo. On loam soils this grass occurs frequently as well, but here the ground cover is less solid than on sandy soil. The nutritive value of Carpet grass is much higher than that of other grass species on the same soil type. This is owing to the fact that regularly Carpet grass is closely cropped by cattle and in this way the herbage remains young and leafy. Compared to other grass species the content of crude fibre is very low.

Luziola spruceana undoubtedly has the highest nutritional value of the aquatic grasses. The content of chlorine in Hymenachne amplexicaulis ("Bamboe grass") is strikingly high, while the content of sulphur is higher than that of Leersia hexandra (Rice grass) and Luziola spruceana. The calcium content in the first-mentioned grass, however, is very low. These differences are also found if the grasses have been collected in the same habitat. The average content of sodium in these species is low, it varies 
from 0,01 to 0,20 . In view of the high temperatures at which cattle must graze this is absolutely insufficient.

The chemical composition of Paspalum conjugatum is interesting. On the drier clay soils this grass may be completely dominant. However, cattle does not feed on this species in fresh condition. This is probably due to the acid taste of the herbage. Hence, the farmers call it Sour grass. The origin of this acid taste is not known, although the presence of tannic acid is suspected. This suspicion might be confirmed by the low pepsin-digestibility of the crude protein. The contents of magnesium and sulphur, however, are obviously high. This is not the case in other grass species found in the same habitat. To confirm this, samples of Bahia, Toco, Lucuntu and Sour grass were taken of the collection at the Government Livestock Farm in June 1960. The contents of magnesium and sulphur were determined in these samples and have been mentioned below (in percentages of the dry matter).

$\begin{array}{lcc} & \mathbf{M g} & \mathrm{S} \\ \text { Paspalum notatum (Bahia grass) } & 0,39 & 0,18 \\ \text { Ischaemum aristatum (Toco grass) } & 0,19 & 0,16 \\ \text { Ischaemum timorense (Lucuntu grass) } & 0,25 & 0,21 \\ \text { Paspalum conjugatum (Sour grass) } & 0,37 & 0,40\end{array}$

A high magnesium content may also be found in other grasses under the same conditions. As for sulphur content Sour grass is absolutely specific, however.

\subsection{Age of the grass}

The quality of roughage to a great extent will be dependent on the age of the herbage. Investigations of VAN Itallie (1934), Appelman and Dirven (1962) and others clearly show that the contents of protein, potassium and phosphorus decrease as the herbage ages. Evidently, there is a positive relation between these contents. 'T HART $(1944,1945)$ proved a similar relation between the mentioned contents in a number of samples from farm fields. Naturally, the extent of the correlation and dispersion of the scattered diagram is influenced by factors such as soil type, drainage, grass species, fertilization, etc.

In the FIGS. 2 and 3 the contents of potassium and phosphorus have been plotted against the protein content in our samples. The potassium content appears to increase sharply as the protein content rises and that according to the regression line: $y=0,137 x+0,72$. With the same protein level the potassium content on sand and loam soils is lower than that on clay soils. Naturally, this may be the result of the poor potassium status of the first-mentioned soil types. The relation calculated between protein and potassium corresponds well with that found by 'T HART (1944, 1945 ) in the Dutch herbage samples, especially with regard to the higher protein contents this relation is obvious. Perhaps the high potassium contents in the tropical grasses are partly due to the higher temperatures which stimulate a higher potassium uptake.

Although the phosphorus content also shows a certain relationship with the protein content, no regression line has been calculated in view of the position of the observations in FIG. 3 . With the same protein content there hardly appears to be any difference in the phosphorus contents on sand and loam soils as compared to that on clay soils. In the Dutch samples the mentioned contents are indeed much higher, but in view of the insufficient phosphorus status of the Surinam soils this could be expected. 
No relation was evident between the contents of calcium, magnesium and sulphur and the content of protein.

Fig. 2. Relation between crude protein and potassium content in the dry matter of Surinam grasses. The dotted line reflects this relation in Dutch grasses $\% \mathrm{~K}$ ('T HART, 1944, 1945)

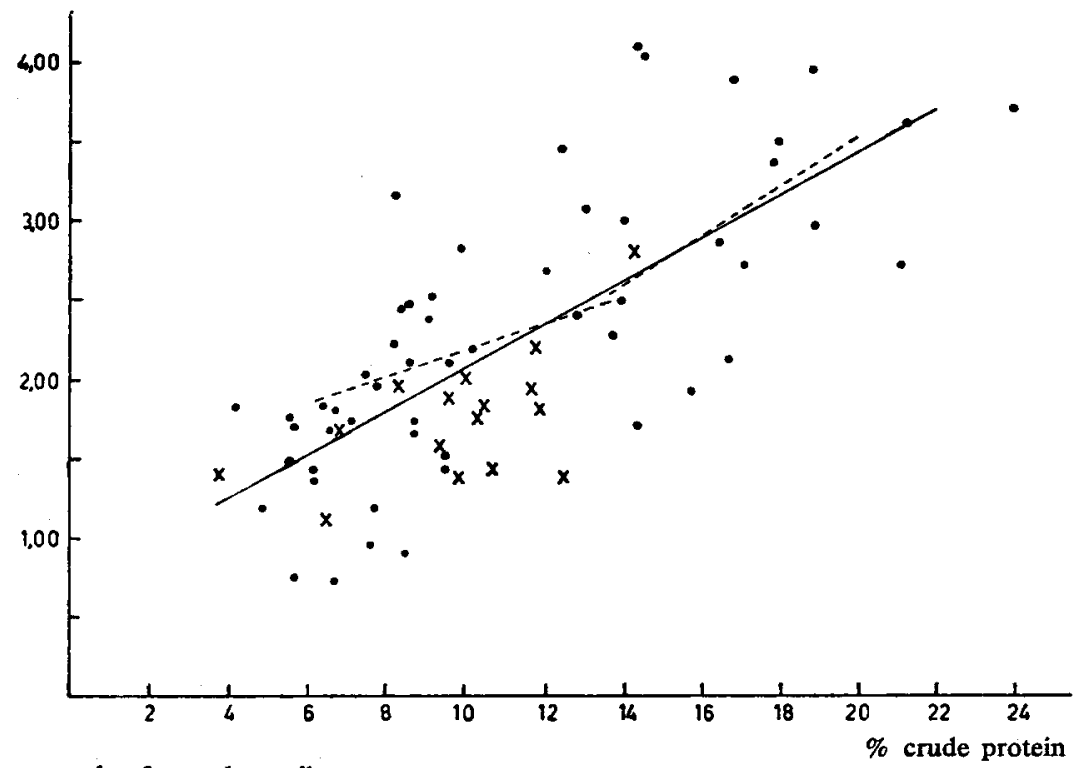

- samples from clay soil

$x$ samples from sandy soil

Fig. 3. Relation between crude protein and phosphorus content in the dry matter of Surinam grasses

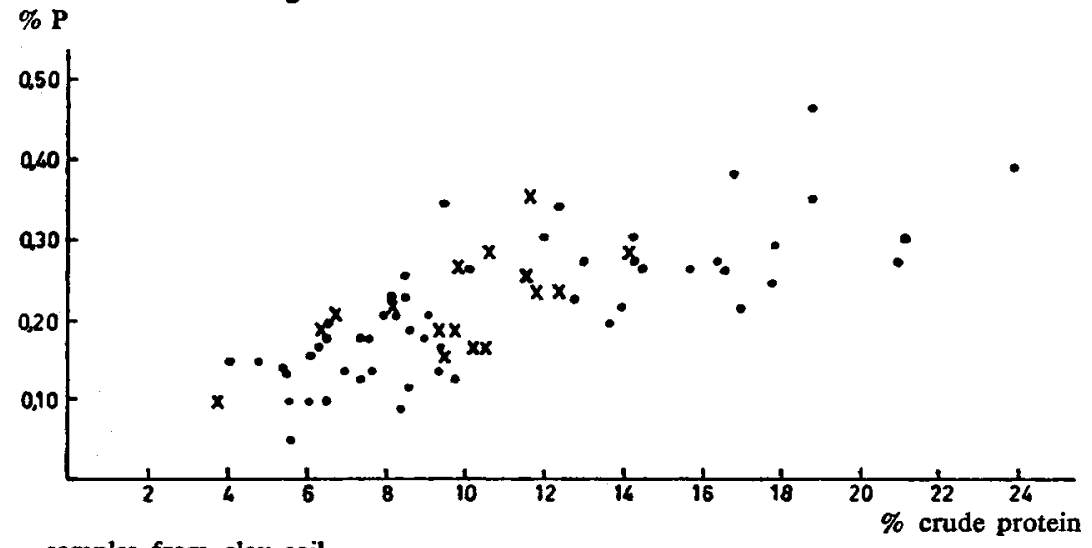

- samples from clay soil

$x$ samples from sandy soil 


\section{5. $\mathrm{D}$ i a $\mathrm{gr}$ a $\mathrm{m} \mathrm{s}$}

In order to get an idea of the ionic ballance of grasses and the physiological importance of the composition of pasture grass the following quantities have been computed after BrouWER and co-operators $(1951,1953)$. In this one gramatom of phosphorus has been valued at 3 equivalents.

Cation total $(\mathrm{CT})=\mathrm{K}+\mathrm{Na}+\mathrm{Ca}+\mathrm{Mg}$ milli-equivalent per $\mathrm{kg}$ dry matter;

Anion total $(\mathrm{AT})=\mathrm{Cl}+\mathrm{S}+\mathrm{P}$ milli-equivalent per $\mathrm{kg}$ dry matter ;

Alkali alkalinity $(\mathrm{AA})=\mathrm{K}+\mathrm{Na}-\mathrm{Cl}-\mathrm{S}$ milli-equivalent per $\mathrm{kg}$ dry matter;

Alkaline-earth alkalinity $(\mathrm{EA})=\mathrm{Ca}+\mathrm{Mg}-\mathrm{P}$ milli-equivalent per $\mathrm{kg}$ dry matter.

The CT- and AT-values have been represented in FIG. 4. The CT-values appear to vary between 546 and 1465 milli-equivalents per $\mathrm{kg}$ dry matter, while the AT-values diverge from 370 to 1256 milli-equivalents per $\mathrm{kg}$ dry matter. The points of the samples of Hymenachne amplexicaulis and Paspalum conjugatum lie normal. In most samples CT is higher than AT, as a result of this the cation excess is positive; the three Paspalum vaginatum grasslands and one sample of Hymenachne amplexicaulis are an exception.

FIg. 4. Cation-anion diagram

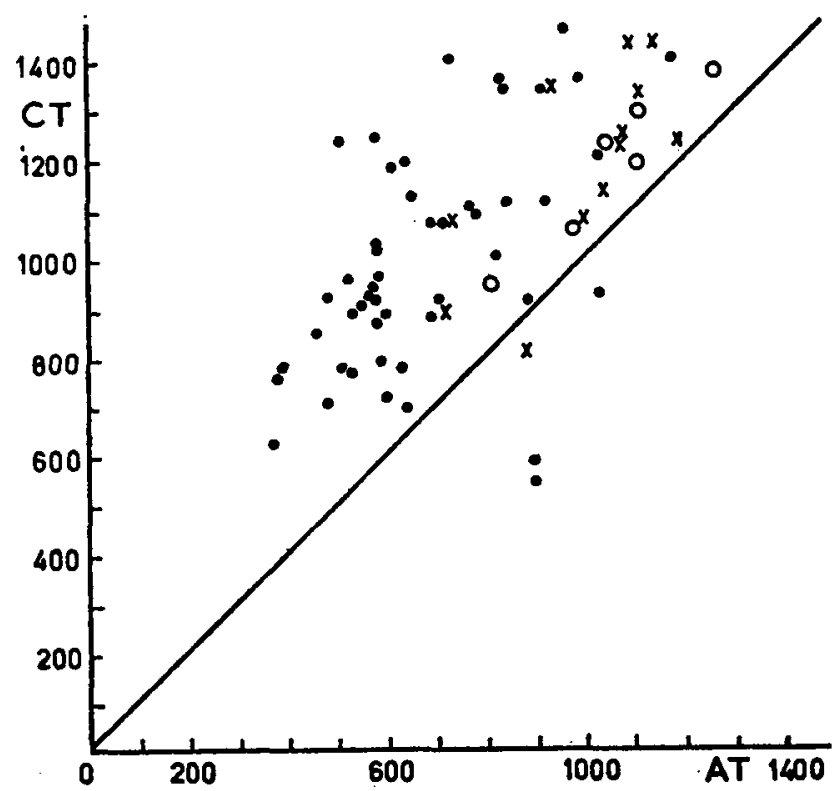

- samples of Paspalum conjugatum

samples of Hymenachne amplexicaulis

$\times$ remaining samples

FIG. 5 represents the relative proportion between potassium, calcium and magnesium in the herbage samples. The milli-equivalents have been reflected as percentages of their sum $(\mathrm{K}+\mathrm{Ca}+\mathrm{Mg})$. Grass samples with high $\mathrm{Na}$-contents have been left out of consideration. The mentioned triangular diagram obviously shows the great dis- 
FIg. 5. Triangular $\mathrm{K}-\mathrm{Ca}-\mathrm{Mg}$-diagram of herbage samples with low Na-contents

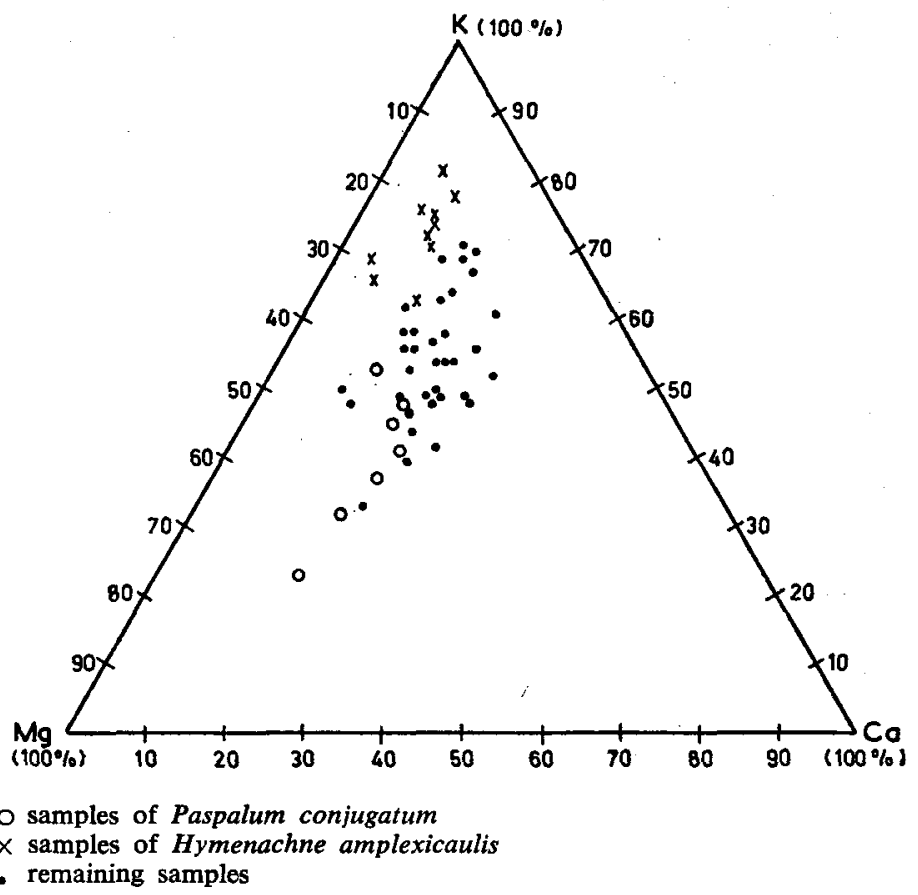

persion of $\mathrm{K}$-values, viz. from $23-83 \%$; with calcium and magnesium this variation amounts to $4-28$ and $11-59 \%$ respectively. The high $\mathrm{K}$ - and low Ca-values in Hymenachne amplexicaulis are striking. Lower $\mathrm{K}$-values are found in Paspalum conjugatum, while the $\mathrm{Mg}$-values are high in this grass.

A triangular diagram of anions has been composed as well. This anion diagram has been represented in FIG. 6. The high $\mathrm{Cl}$-contents in the samples of Hymenachne amplexicaulis do not appear to be related to high $\mathrm{Cl}$-values. The mentioned samples do not take a special place in the diagram with regard to the other samples and are rather regularly distributed in the scattered diagram. On the other hand, the high S-values of Paspalum conjugatum are very obvious.

Finally, the alkalinity diagram of the samples analysed has been reflected in FIG. 7 . This diagram gives an impression of the dispersion and correlation of the alkalineearth alkalinity and alkali alkalinity. EA appears to fluctuate between -215 and +893 . The lower values are found in a number of samples from a wet habitat, as Hymenachne amplexicaulis, Leersia hexandra and Luziola spruceana. The AA-values are between -800 and +650 . This value is negative in $36 \%$ of the samples. It concerns samples in which Paspalum conjugatum, Paspalum vaginatum and Fimbristylis miliacea are dominant. According to investigations of BRouWER (1952) these low AA-values in the pasture grass may be related to an acid reaction of the urine of cattle. This appeared to be indeed the case (Appelman, Dirven, Ehrencron, 1962). 
Fig. 6. Triangular anion diagram

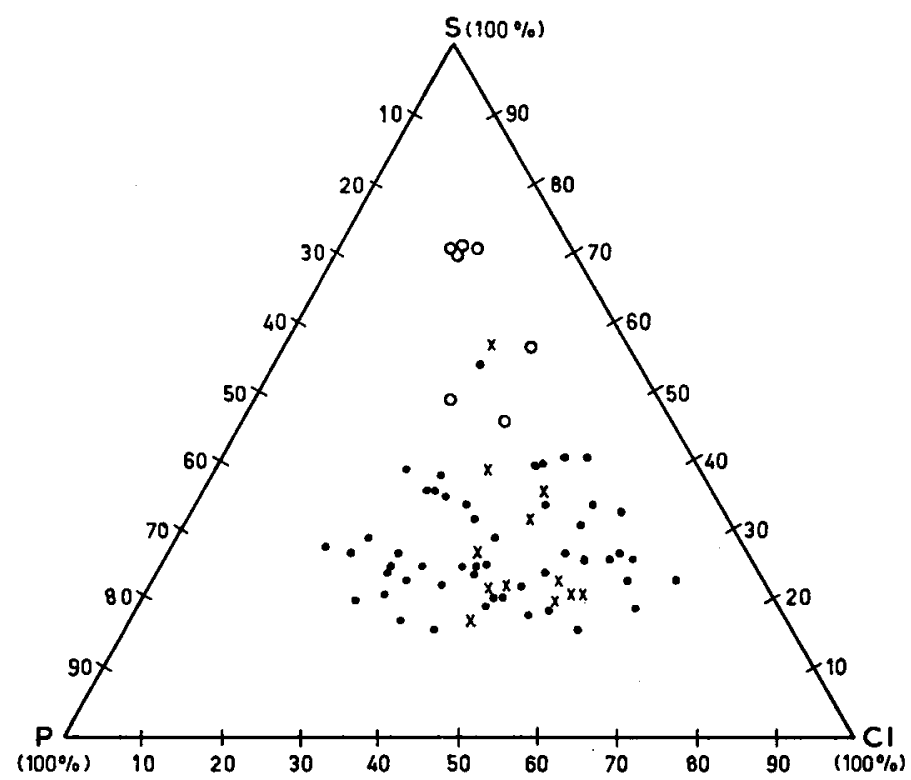

O samples of Paspalum conjugatum

$\times$ samples of Hymenachne amplexicaulis

- remaining samples

FIg. 7. Alkalinity diagram. The line shows the cation excess $\mathrm{TA}(\mathrm{AA}+\mathrm{EA})=250$

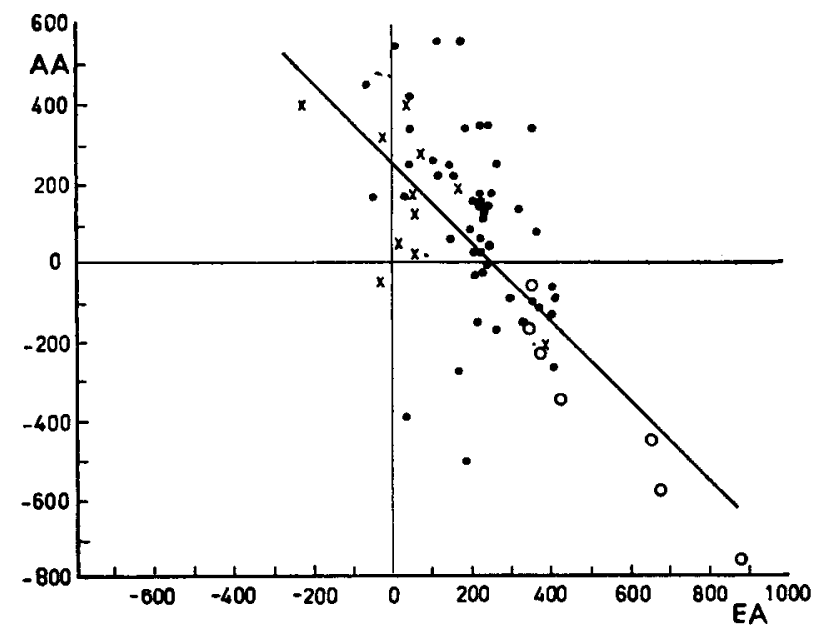

O samples of Paspalum conjugatum

$\times$ samples of Hymenachne amplexicaulis

- remaining samples

Neth. J. agric. Sci., Vol. 11 (1963) No. 4 (August) 


\subsection{Trace elements}

The contents of the trace elements cobalt, molybdenum and copper have been analysed in a number of samples as well. The average contents and the variation belonging have been reflected in TABLE 5 .

TABLE 5. The average contents of trace minerals and belonging variation in terms of $\mathrm{mg}$ per $\mathrm{kg}$ dry matter

\begin{tabular}{lcll}
\hline & $\begin{array}{c}\text { Number of } \\
\text { determinations }\end{array}$ & Average & \multicolumn{1}{c}{ Variation } \\
$\mathrm{Co} \ldots \ldots \ldots$ & 20 & 0,28 & $0,66-0,80$ \\
$\mathrm{Mo} \ldots \ldots \ldots$ & 19 & 1,07 & $0,10-5,10$ \\
$\mathrm{Cu} \ldots \ldots \ldots$ & 24 & 4,5 & $0,8-15,8$ \\
\hline
\end{tabular}

Undoubtedly, the variation in the cobalt contents for the greater part is due to the contamination of herbage samples by soil particles. Exceedingly high cobalt contents are found in the fraction smaller than $2 \mu$. And these smallest particles are the very ones that contaminate the herbage. The variation in soil particles amounted to $0,1-3,8 \%$ in the samples analysed; in $70 \%$ of the samples this percentage lay below 1,0. The cobalt content in the samples from grassland on clay soil, in fact, proved to rise sharply as the percentage of soil particles increased. The average cobalt contents in the herbage samples from grasslands on sandy and clay soil amount to 0,15 and $0,35 \mathrm{mg}$ per $\mathrm{kg}$ dry matter; the percentage of soil particles 0,5 and 1,2 respectively. The cobalt content in $15 \%$ of the samples is below $0,10 \mathrm{mg}$, although it should be mentioned that the desired minimum content is not known. The contrary is the case with the cobalt contents in the soil (soluble in $21 / 2 \%$ acetic acid). A content of $0,30 \mathrm{mg}$ Co per $\mathrm{kg}$ soil or less is considered insufficient in this case. In view of this limit Dirven and EHrencron (1962) think that cobalt deficiency is to be expected on sand and loam soils.

Not much is known about molybdenum deficiency in cattle. Indeed, very high molybdenum contents are sometimes found, and these may lead to the occurrence of scour. However, the contents we have found are on the safe side. There is a considerable variation in the contents, but no difference has been found in the molybdenum content of herbage from sandy soil and that from clay soil.

Inspection of the average copper content shows that the copper nutrition of the Surinam cattle population is insufficient. In 13 samples out of 24 the copper content is even below $4,0 \mathrm{mg}$ per $\mathrm{kg}$ dry matter. The copper contents of herbage from sandy soil and clay soil hardly appear to differ. Soil analysis also has clearly indicated the poor copper status of the Surinam grassland soils, so that additional copper should be applied.

\section{ACKNOWLEDGEMENT}

The author is grateful to Dr. W. B. DEYs for the chemical analyses carried out and to Miss A. H. van Rossem for translation of the manuscript. 
Appelman, $\mathrm{H}$.,

J. G. P. Dirven and

A. R. TJong A Hung

Appelman, H., and

J. G. P. DIRven

Appelman, $\mathrm{H}$.,

J. G. P. Dirven and

V. K. R. EHRENCRON

Brouwer, E., and

A. J. VAN DER VLIERT

Brouwer, E.

and S. BRANDSMA

Deys, W. B., S. Bosch and J. WIND

DiRVEN, J. G. P.

and V. K. R. EHRENCRON

Dijkstra, N. D., and

J. G. P. Dirven

Frens, A. M.

FrICKERS, J.

HART, M. L. 'T

ITALlie, Th. B. VaN

Prado, H. Del

\section{REFERENCES}

1962 Orienterende proeven omtrent de droge stofopname door rundvee. Versl. Rapporten Dept. LVV. No. 56.

1962a Zoutopname door slachtvee. De Sur. Landb. 10, 27-29.

1962b De invloed van de maaitijd op de chemische samenstelling van verschillende grassoorten. De Sur. Landb. 10, 95-102.

1962 De $\mathrm{pH}$ in urine van melkvee op de Landsboerderij. De Sur. Landb. 10, 161-167.

1951 Over de zuur-base-evenwichten in hooi, in normaal gras en in gras dat aanleiding geeft tot haemoglobinurie (bloedwateren) of tot grastetanie (kopziekte) bij runderen. Meded. Landb.hogesch. Wageningen. 51, 3: 73-90.

1952 On the base excess, the alkali alkalinity, the alkaline-earth alkalinity and the mineral ratios in grass and hay with reference to grass tetany and other disorders in cattle. The British Veterinary Journal. 108, 4: 123-131.

1953 Over de minerale bestanddelen en hun onderlinge verhoudingen in verschillende voedermiddelen en rantsoenen. Meded. Landb.hogesch. Wageningen. 53, 3: 31-73.

1955 De minerale samenstelling van weidegras in verband met kopergebrek bij rundvee. Versl. CILO 1955, 88-100.

1954 De natuurlijke graslanden in Suriname. 3. De voederwaarde. De Sur. Landb. 2, 105-109.

Sporenelementen in weidegronden (manuscript).

1962 Digestibility and feeding value of some tropical grasses and kudzu. Neth. J agric. Sci. 10, 275-285.

1962 Wat is goed gras voedingstechnisch gezien. Kali. 52, 63-68.

1941 De samenstelling en voederwaarde van enkele Surinaamse veevoedermiddelen. Versl. Depart. Landb.-Econ. Zaken Suriname 1941. 121-125.

1944 Over de gehalten aan enkele minerale bestanddelen in gras. Landbouwk. Tijdschr. 56/57, 477-487.

1943 De chemische samenstelling van een aantal afzonderlijke grassoorten in verschillende groeistadia. Versl. Landbouwk. Onderz. No. 40 A, 639-693.

1961 LVV in 1960. De Sur. Landb. 9, 143-232. 